\title{
Sound and Sense in Select Ibibio Lullabies
}

\author{
Friday A. Okon \\ Department of English University of Uyo, Uyo. Nigeria \\ Email: fridayokon@uniuyo.edu.ng
}

How to cite this paper: Okon, F. A. (2021). Sound and Sense in Select Ibibio Lullabies. Art and Design Review, 9, 180-197. https://doi.org/10.4236/adr.2021.92015

Received: April 14, 2021

Accepted: May 23, 2021

Published: May 26, 2021

Copyright $\odot 2021$ by author(s) and Scientific Research Publishing Inc. This work is licensed under the Creative Commons Attribution International License (CC BY 4.0).

http://creativecommons.org/licenses/by/4.0/

\begin{abstract}
This paper sets out to examine select traditional Ibibio lullabies for their sound effects and the sense (impressions), they create in the ears and minds of the infant audience. To fulfill this objective, the researcher undertook field work with the help of an assistant, and recorded ten (10) lullabies through interaction with five specialists who are professional baby minders. The ten songs form the texts that have been analyzed in this paper. The theoretical framework for this study is the Cultural Approach, with a strong bias for the literary devices deployed by the performers in the songs. The finding of this study is that the performance of lullabies as credible tools of child rearing among the Ibibio is fast dying out, as its performers today are mainly elderly women-grandmothers, who at some point in their lives had engaged in the art as mothers, paid baby sitters or grandmothers taking care of their grandchildren. The analysis of the few texts of this subgenre collected from the field, have proven that lullabies are rich in aesthetics and other stylistic devices. On the whole, these lullabies prove to be credible poetry, just as any found anywhere in the world. For this reason, this study takes the position that more studies should be undertaken on this neglected aspect of Ibibio oral literature, while also devising a means of collecting, documenting and preserving texts of this subgenre that are still in circulation, for the coming generation.
\end{abstract}

\section{Keywords}

Cradle Songs, Ibibio, Lullabies, Sound, Sense, Oral Poetry

\section{Introduction}

Lullabies or cradle songs can be categorized among Special purpose poetry, in African oral literature. Special purpose poetry in African orature has to do with any song, chant or recitation that is performed only in the course of performing certain special tasks (Onuekwusi, 2015). Other kinds of songs classified under 
this category are hunting songs, work songs and war songs. Lullabies are well known as songs or chants rendered with the sole purpose of lulling babies and younger children to sleep, or at least, quietening them from persistent crying. According to Wikipedia, a lullaby or cradle song, is a soothing song or piece of music that is usually played for (or sung to) babies or younger children. The word "Ibibio" signifies a language (Essien, 1986, 1990) and an ethnic group (Udo, 1983) that inhabit Akwa Ibom State in the South-South geopolitical zone of Nigeria. The objective of this research is to analyze the lullabies to showcase the use of sound effects and other aesthetic devices, which are seen as having the overall effect of calming crying babies or lulling them to sleep.

\section{Literature Review}

Lullabies in Ibibio land are called ikws ádèp-áyin or ikws-úkàmà àyin, and are primarily performed by adults, (who may be) either the mothers of the babies concerned, or assigned caregivers or paid babysitters or minders, as the case may be. Ruth Finnegan (2012) acknowledges the place and importance of lullabies in the corpus of African orature, and proceeds to examine a few representative examples from across the continent. However, of the few she highlights, none is drawn from Nigeria, not to mention any from Ibibio land, hence this study. Scholars of Ibibio extraction on their part, have not done much to improve the present state of paucity of research on Ibibio lullabies. For example, Prof. Uwemedimo Iwoketok who has researched into Ibibio children's games (Iwoketok, 1995, 2001, 2005; Etuk, 1989), did not include lullabies in the corpus of her research interests; Prof. Luke Eyoh who researched into Ibibio work and moonlight songs (Eyoh, 2003), did not examine lullabies as it seems that it was not within the scope of his work at the time he carried out his research. In spite of the fact that much work has not been done on Ibibio lullabies, it "still enjoys a rich currency existing alongside written literature (Chukwuma, 1994). The lullaby still enjoys a rich currency because it is part of a living tradition of a people (Ikiddeh, 1997), since children are being born every other day, and hence, the need to retain the services of baby-sitters remains high.

Ibibio lullabies are full of sound and sense. Sound here implies the melodious sounds captured in the lullabies that imbue them with their liquidity, rhythm and cadence. In this regard, sound elements and sound devices like puns, assonance, and ideophones are deployed. In almost all cultures and or societies, there has been a recognition of the attraction that sounds hold for young children (Machado, 1999: p. 4). In order to capture and hold the attention of children, sound elements have to be deployed. Sense implies the meaning of the words of the songs within the context of the situation that necessitated them.

It is necessary here to observe that in Ibibio land, care of infants or babies is usually reserved for the female gender. Men seldom carry out this responsibility. Where they do, it is on an ad hoc basis; either they are the fathers of the infants or the baby's older male siblings or cousins who have been requested by the ba- 
by's mother to lend a helping hand for a brief period while the mother attends to other duties. Culturally, among the Ibibio, child-minding is not a preserve of the male, but that of the female. That seemingly, explains why lullabies are regarded as one of the "women's oral genres" (Kolawole, 2007). In most of the song situations below, we shall make use of female pronouns because all the specialists who supplied data for this research were female; some are mothers, some are grandmothers and at least, two are experienced elderly caregivers who are hired by families who need their services. Justification for analysis of ten lullabies is predicated on the fact that each lullaby is unique, and even though they share a certain common ambience, they are distinct because they highlight different themes and different emotional states of mind of the performers.

\section{Sound and Sense in Select Ibibio Lullabies}

Ten lullabies were selected for analysis in this essay because they showcase in their typical form, the various sound elements that recur in many Ibibio children's play songs. Besides, these selected lullabies capture the different emotional states of the performers of the songs under review, which in itself, highlights the sense impressions or meanings that are derived from the songs.

\section{Lullaby \# 1}

Áyin, dòp úyò-o-o!

Child, keep quiet o-o!

Áyáárá mkpàfáfiáñ.

(May) a wild creeping plant.

Ámiá ùkà mbáñ!

Slap your mother on the jaw!

\subsection{Analysis}

This lullaby appears to be sung by an impatient or dissatisfied baby minder. In this song, she shows no respect for her mistress, the baby's mother, hence she wishes that a wild creeping plant would slap her on the cheeks. She sings these words boldly before the infant, knowing that as an infant the child has not acquired verbal sophistication enough to be able to report her (the minder) to her mother. It is also possible that the incessant crying of the child exasperates the minder. Unable to contain her emotions much longer, she voices out her frustration in the above song, behind the child's mother's back. However, this kind of reaction is unusual; it is the exception rather than the rule.

\subsubsection{The Use of Assonance}

Assonance is deployed to create sound in this song, and in all the other songs to be treated in this article. The predominant sounds employed in this song are /a/ and /o/. For example, /a/ features predominantly in lines 2 and 3, thus:

Áyáárá mkpàfáfiáñ

Ámiá ùkà mbáñ!

The /o/ sound is only dominant in the first line thus: Áyin, dòp úyò-o-o!

\subsubsection{The Use of Interjection}

The song is an exercise in interjection. The major sign-post in graphology that 
indicates the use of interjection is the use of the exclamation mark. An interjection becomes necessary to indicate that the speaker is in deep or high emotions. The speaker in this case, is evincing deep emotion of anger and frustration rolled into one, at the long absence of the baby's mother, an occurrence that has caused the baby to cry incessantly, rejecting every palliative meant to calm him/her down.

\section{Lullaby \#2}

Yàk Mmá ákâ ùdùa. Let mother go to the market.

Ákédép àgidi áyin. And buy the child's agidi.

Ádâd ások nsék áyin! And bring to the baby!

\subsection{Analysis}

The baby-sitter persona in this lullaby is a calm and collected personality, whose main aim is to lull the baby to sleep. The song therefore, tells the child the reason the mother has gone to the market, namely: to buy the baby's food-agidi. Agidi is a semi-solid food made from the starch of ground maize; it is fed to infants who have not been inducted into eating solid food. Agidi is a tasty meal that is introduced to infants during weaning. By telling the infant that her mother had gone to procure her food, it is expected that this information would calm the child down until the mother returns from wherever she went.

\subsubsection{The Use of Assonance}

This song also makes predominant use of assonance to create pleasing sounds. The predominant sounds here are /e/, /a/ and / $/$ / sounds. For example, /a/ is predominant in the following line- "Yàk Mmá ákâ" (line 1).

\subsubsection{Adopting a Foreign Term}

The innovation in this song is the use of a foreign term which has become a norm in Nigeria as the various ethnic groups interact. The loaned word is agidi. Agidi is neither an Ibibio word nor an English word, as the case may be. It is a word borrowed from either Yoruba or Igbo. By this borrowing, it shows that the Ibibio are living in a multicultural society, and therefore borrowings across cultural boundaries become an increasing norm.

\section{Lullaby \#3}

$\begin{array}{ll}\text { Kpé Ó! Kpé Ó! Kpé Ó! } & \text { Sorry O! Sorry O! Sorry O! } \\ \text { Ànié inám? } & \text { Who hurt him (or her)? } \\ \text { Kûnám ènyé O! } & \text { Don't hurt him (her) O! } \\ \text { Mbààk Èkà ámo! } & \text { For fear of his/her mother! } \\ \text { Mbààk Ėté ámo! } & \text { For fear of his/her father! } \\ \text { Mbààk Èkà-èkà ámo! } & \text { For fear of his/her grand-mother! }\end{array}$

\subsection{Analysis}

Like the second song above, this one is also sung by a sympathetic child care-giver. The persona is trying to soothe the baby to sleep, hence the words, “Kpé Ó! Kpé Ó! Kpé Ó!” (Sorry O! Sorry O! Sorry O!). The next line is a ques- 
tion: “Ànié inám?" (Who hurt him/her?). This is followed by a response from the persona 'Kûnám ènyé O! (Don't hurt him/her O!), for fear of his/her parents or grandparents. From the personal experience and observation of the activities of babysitters by this researcher, children love to hear that somebody hurt them and made them cry, and feel elated that such a person would receive punishment from their parents. This kind of song is usually effective in calming children's nerves and stops them from crying, as they await offending adults to be punished by their "all-powerful" parents or older siblings.

\subsubsection{The Use of Assonance}

Assonance, once again, is predominant in this song. Like the other songs before it, the predominant sounds in this song are $/ \mathrm{a} /, / \mathrm{o} / \mathrm{/} / \mathrm{e} /$ and $/ \mathrm{o} /$. An example is $/ \mathrm{a} /$ as in the word "Mbàak". These sounds provide the rhythm that propels the song forward. There are other stylistic /aesthetic devices used in the song such as interjection, rhetorical question device and repetition.

\subsubsection{The Use of Interjection}

Interjection is made use of in the first line of the song, thus: "Kpé Ó! Kpé Ó! Kpé Ó!" (Sorry O! Sorry O! Sorry O!). This time, the emotion expressed in the lines is that of empathy for the baby.

It also shows that there is a strong bond of affection between the baby and the caregiver.

\subsubsection{The Use of Rhetorical Question Device}

The persona employs rhetorical question in line 3: “Ànié inám?” (Who hurt him/her?). As the question is asked to nobody in particular, the child calms down to see who will respond to the question. This is a stylistic device that adds pep to the song and peaks the curiosity of the baby as well.

\subsubsection{The Use of Repetition}

Repetition is a major stylistic device in African oral literature meant to enhance and maintain rhythm and tempo in a short song text. In this song, repetition manifests in the use of the word "Mbààk", which occurs between lines 4 and 6 . However, in each case where the word "Mbàà" occurs, another noun is added to go with it, to add something new to the repeated word. This device is what is known as incremental repetition:

Mbààk Èkà ámo!

For fear of his/her mother!

Mbààk Èté ámo!

For fear of his/her father!

Mbààk Èkà-èkà ámo!

For fear of his/her grand-mother!

Though repetition is primarily for emphasis, in the case above, it is primarily meant to enhance the length and rhythm of the song.

\section{Lullaby \#4}

Nkwà ñkoriko, ùkàá?

Èkà mmi mmo ké òkpò ñwıb.

Áyém sé ánám ono Ũñwà-ùñ wà.
Little snail's egg, where is your mother? My mother is in the bosom of weeds. Searching for what to bring home for 
Ùñwà-ùñ wà ádó àdiá mkpo.

Àmi ami ndó àtié ábioñ.
Ũñwà-ùñwà.

Ũñwà-ùñwà is the one who eats.

I and I am the one who goes hungry.

\subsection{Analysis}

The above song is sung by a baby-sitter who feels that the mother of the child she is baby-sitting is not taking good care of her. This explains why she fondly calls the baby "Nkwà ñkoriko" (little snail's egg) (line 1a). The person answers the question she herself asks the baby: "ùkàá?" (where is your mother?) (line 1b), with the response:

"Ėkà mmi mmo ké òkpò ñwıb". (My mother is in the bosom of weeds).

Áyém sé ánám ono Ũñwà-ùñwà (Searching for what to bring home for Ũñwà-ùñwà).

Then, the accusation and denunciation comes:

Ùñà-ùñwà ádó àdiá mkpo Ũñwà-ùñwà is the one who eats Àmi ami ndó àtié ábioñ. I and I am the one who goes hungry.

The minder in a mocking tone says that it is the baby that eats while the baby-sitter goes hungry. These last two lines indicate that the baby's mother does not take good care of the childminder; this is a potentially dangerous situation for the baby in the care of the minder when the mother is not around. The above situation buttresses an Ibibio proverb that says: "Idiokko ádêp ifon áyin; idiokko áyin ifon ádêp" (meaning: "it cannot be bad with the minder and good with the child; it cannot be bad with the child and good with the minder"). In other words, this Ibibio belief holds that when the minder is well taken care of, she in turn will take good care of the baby under her watch.

Assonance creates the sounds that propel the song forward. The predominant sounds in the song are /a/, /e/, /u/. Equally noteworthy are the stylistic and aesthetic devices deployed in the song, as follows: the use of epithet/sobriquet, the use of rhetorical question device and the use of declaratives.

\subsubsection{The Use of Epithet/Sobriquet}

This is a feature of African speech whereby people are addressed not by their real names, but by pet-names either of endearment or of abuse. In this song, the baby is called an endearing pet name: "Nkwà ñkoriko" (Little snail's egg). This pet name illustrates the baby-sitter's relationship with the baby she is minding. The next pet name she gives the baby is "Uñnà-ùñwà". The name portrays the birth order of the baby, as the second female child of her parents, but in this case, it is doubled for emphasis as a form of endearment. Little children love to be pampered with pet names. The use of these pet names lightens the venom that the minder harbors for the baby's mother whom she regards as not treating her well.

\subsubsection{The Use of the Rhetorical Question}

The first line of the poem ends in a rhetorical question: "ùkàa?" (Where is your mother?). This question, directed at the baby who is unable to respond, is ans- 
wered by the baby-sitter herself in the succeeding lines of the song. The rhetorical question does not only enhance the meaning of the song, but also enhances the rhythm as well!

\subsubsection{The Use of Declaratives}

Declaratives are sentences that state a fact. In the last two lines of the song the baby-sitter states a fact that brooks no argument:

Ũñwà-ùñà ádó àdiá mkpo. UUñà-ùñà is the one who eats.

Àmi ami ndó àtié ábioñ. I am the one who goes hungry.

This declarative is an indicting statement by the baby-sitter against the mother of the child. This is an innuendo that implies that the mother of the child is not only stingy in giving food and other delicacies to the baby-sitter, but that she probably neglects the general welfare of the latter.

\section{Lullaby \#5}

Nsinám áyin-O?!

What ails the child- $\mathrm{O}$ ?!

O-ho! O-ho! O-ho!

O-ho! O-ho! O-ho!

Ayin dòb úyò-O!

Child, stop crying-O!

O-ho! O-ho! O-ho!

O-ho! O-ho! O-ho!

Ùkà ákâ iñwáñ-O!

Your mother has gone to farm-O!

O-ho! O-ho! O-ho!

O-ho! O-ho! O-ho!

\subsection{Analysis}

This song, like the others, gives the baby information as to the whereabouts of its mother-which is that she has gone to the farm. For this reason, the baby is cajoled to stop crying and to keep quiet. The reasons for the child's mother going to the farm are not divulged to the child. The child is expected to be satisfied with whatever information is released to it and not to worry about whatever information is withheld. However, we know that implied in the mother's farm-going is the fact that she will come back home with food stuff for the feeding of the baby as well as other members of the household.

Some of the stylistic and aesthetic features deployed in the song include the rhetorical question and interjection.

\subsubsection{The Use of the Rhetorical Question Device}

This device is used in the first line of the song which says: "Nsinám áyin-O?!" (What ails the child-O?!). This statement is both an interrogative as well as an interjection; that is why both marks are applied. As an interrogative, it demonstrates the child-minder's perplexity as to why the baby is not responding to petting but continues to cry. As an interjection it demonstrates frustration at the baby's ceaseless crying.

\subsubsection{The Use of the Interjection}

There is profuse use of the interjection in this song. For example, the first line of the song is equally an interjection as it is also an interrogative. Reason why it functions as an interrogative has been treated above. As an interjection, "Nsinám 
áyin-O!?" (What ails the child-O!?) indirectly imputes on the baby that it must stop crying and keep silent, as the minder croons the song and rocks the baby to the song's rhythm. The interjection, "O-ho! O-ho! O-ho!" which is found in lines 2, 4 and 6, function as space-fillers and rhythm-enhancers that imbue the song with its unique melody. It must be noted that in this song, the baby-sitter is mainly interested in calming or lulling the baby to sleep, and not to express her own emotions concerning her own welfare.

The predominant sound in the song is /o/ as in: O-ho! O-ho! O-ho!

Lullaby \#6

$\mathrm{O}-\mathrm{O}-\mathrm{O}-\mathrm{O}-\mathrm{O}$ !

Áyin dáiyá dòp úyò! Kpé O! Kpé O! Kpé O!

Áyin dáiyá dòp úyò!

Ùkà ákâ ùdùà idim-O!

Ákédéé mé ntək mkpo!

Ádâd ások ádêb-áyin.

Ádià át $\Lambda \mathrm{m}$ áyin ákámà!

$$
\mathrm{O}-\mathrm{O}-\mathrm{O}-\mathrm{O}-\mathrm{O} \text { ! }
$$

Baby, sleep and be silent! Sorry O! Sorry O! Sorry O!

Baby, sleep and be silent!

(So that) mother may go to river market-O!

To buy little things!

For the baby-sitter.

So that she may eat and take good care of baby!

\subsection{Analysis}

The song above is another attempt by the child minder to quieten the child and if possible, lull her to sleep. In the song, the minder tells the child that she (minder) is sorry that she (baby) is crying. That is what "Kpé O! Kpé O! Kpé O!" in the song stands for. The expression can also mean: "please, calm down". In the next five lines, the minder tells the child to go to sleep and to be quiet because her mother has gone to the river market to buy delicacies for the minder so that she would eat and take good care of her (the baby). This song contrasts sharply with Song \#4, where the minder implies that she is ill-treated. Rather, in this song the minder acknowledges the fact that the baby's mother's journey to the river market is to acquire food stuff for the baby minder who would eat and be satisfied and then take good care of the child in her custody. This reaffirms the Ibibio proverb again which says that "ifonn śyin idiok ádèp; ifonn ádèp idiok áyin" (If it is well with the baby, it will be well with the minder; if it is well with the minder, it will be well with the baby). The main aesthetic/stylistic feature in this song is the use of interjection.

\subsubsection{The Use of Interjection}

This song is an exercise in the use of the interjection. This is observed in all the lines of the song beginning from the first line which goes thus: "O-O-O-O-O-O!". All the lines carry the exclamation mark to show that they are interjections, for example: "Kpé O! Kpé O! Kpé O!"

The predominant sound in the song is /o/, as in "O-O-O-O-O $-\mathrm{O}$ " and in "Kpé O! Kpé O! Kpé O!"

\section{Lullaby \#7}

Áyin dòb úyò.

Child, keep quiet. 
Ùkà ekékà iñwáñ-O!

Dád mkpo ntək áyin sok áyin.

Náñá áyin ádòp úyò.

Àdáiyá idáp!
Mother went to the farm-O!

Bring home to baby her delicacies.

So that baby may eat and be quiet.

And sleep!

\subsection{Analysis}

The song above is a departure from the song that preceded it. In song \#6 above, the minder concentrates on the delicacies she stands to benefit from, from the goods the baby's mother would bring back from the river market. However, in this song, the baby-minder concentrates on the delicacies the baby stands to gain from her mother's journey to the farm. In the song, the minder tells the child to stop crying and keep quiet, as her mother has gone to the farm to fetch her some delicacies (mkpo ntək áyin), so that she can eat and sleep. This is a child minder whose sole concern is the welfare of the baby in her custody. Unlike some of the earlier songs where the child minder only addresses the child, in this one, the minder addresses both the child and the mother. For example, in the first two lines of the song, the minder addresses the child:
Áyin dòb úyò.
Child, keep quiet.
Ùkà ákékà iñwáñ-O!
Mother went to the farm-O!

However, in the last three lines, the minder addresses the baby's mother in absentia:

Dád mkpo ntək áyin sok áyin. Bring home to baby her delicacies.

Náñá áyin ádòp úyò.

So that baby may eat and be quiet.

Àdáiyá idáp!

And sleep!

The stylistic/aesthetic features inherent in this song are interjection and apostrophe.

\subsubsection{The Use of Interjection}

This song makes use of interjection in almost all the lines. However, the most outstanding example of this device is in line 2 above: 'Ùkà ákékà iñwáñ-O! (Mother went to the farm-O!).

\subsubsection{The Use of Apostrophe}

An apostrophe is an address to someone who is not physically present at the time and place of the speech act. The baby minder in this song makes use of this device by addressing the baby's mother in absentia, as follows:

Dád mkpo ntək áyin sok áyin. Bring home to baby her delicacies.

Náná áyin ádòp úyò. So that baby may eat and be quiet.

Àdáiyá idáp! And sleep!

From the above, the baby is given the impression that her mother hears everything the minder says, and would likely come back home with delicacies for the baby. By this statement, the minder gingers the hopes and expectations of the baby, as she looks forward to the arrival of her mother. This expectancy is meant to make her quieten down while waiting for her mother's arrival. 
Assonance as usual, is deployed in this song because of the tonality of the Ibibio language (Essien, 1990: p. xvii). The song makes use of the /a/, /e/ and /o/ sounds in order to create assonance and melody in the ears of the baby, and thereby lull her to sleep.

\section{Lullaby \#8}

Èkà áyin ákéká úké-O?!

Ákékà ùdùà Ókòpèdi!

Ákédép ikpoñ Ókòpèdi!

The baby's mother went to where-O?!

Àmá ádiá ádù úwém!.... She went to Okopedi market!

To buy Okopedi cocoyams!

After eating she will live long!....

\subsection{Analysis}

The above song enquires as to the whereabouts of the child's mother and also answers the question by stating that the mother had gone to Okopedi market to buy cocoyams. The song follows up this event by saying that when the child's mother eats the cocoyams she would live long. This is a song that gives the hearer information and hope. The information is in three phases, namely: (a) The whereabouts of the child's mother; (b) The mother's activity while at the location; and (c) The outcome of the activity she had engaged in.

The first information given is about the whereabouts of the mother. The answer is that she went to a distant market located at a place called Okopedi. There are several places in Akwa Ibom State by this name: any of them could be the subject of this enquiry. The second information that follows is what the mother's mission to Okopedi was. The answer again, is provided by the minder-the purchase of cocoyams. It appears that the cocoyam variety obtained at Okopedi is special. This observation is borne out by the third information given by the minder when she says, 'Àmá ádiá ádù úwém!.... (After eating she will live long!....). The implication is that the baby's mother undertakes these activities for the sake of the baby: that she may live long to take care of her baby. But this bit of information is not made known to the baby. If she (the baby) is old enough, then she would have inferred this much. The baby cannot be told this last part because she is not old enough to digest such information, therefore, it is not mentioned.

The stylistic/aesthetic devices employed in this song are: the use of the interrogative device, the use of interjection and the use of ellipsis.

\subsubsection{The Use of the Interrogative Device}

This device is used in the first line of the song to enquire of the whereabouts of the child's mother. 'Èkà áyin ákéká úké-O?! (The baby’s mother went to where-O?!). The incessant crying of the child is usually interpreted by the minders as the baby's way of asking after its mother, hence the minder asks the question aloud to the hearing of the baby. By this, the baby quietens down to hear the response that would be given as answer to the question.

\subsubsection{The Use of the Interjection}

The entire song is an exercise in the use of interjection. For example, line 1 is 
both an interrogative as well as an interjection, hence, the two signs (the question mark and the exclamation mark) are used simultaneously thus: "Èkà áyin ákéká úké-O?!” (The baby's mother went to where-O?!). Equally, other lines of the song continue as interjections. For example, the second and third lines of the song reinforce this technique as follows:

Ákékà ùdùà Ókòpèdi! She went to Okopedi market!

Ákédép ikpoñ Ókòpèdi! To buy Okopedi cocoyams!

The idea behind the use of this device is to convince the child about the whereabouts of his/her mother and the activity his/her mother is carrying out there. Behind this information is the implied assurance that the mother would soon be back to take care of her baby.

\subsubsection{The Use of Ellipsis}

An ellipsis is a device by which some information is consciously held back, for reasons best known to the supplier of the information. In other words, it is a figure of syntax, by which one or more words, which are obviously understood, are omitted. In the case of the song above, the last line is presented in ellipsis thus: “Àmá ádiá ádù úwém....!" (After eating she will live long....!). The ellipsis keeps out some information which is obvious to the adult listener to the song, but which is lost on the child. The missing information is that when the mother eats Okopedi cocoyams, she will live long to take care of her dearly beloved child. If there is anything Ibibio women abhor, it is for a mother to die leaving a tender, hapless baby behind. If anything, it is believed that no matter who takes care of a baby, it is only the child's mother who is best endowed to give qualitative care to her own baby.

This further reinforces an Ibibio proverb which says: "údúàñ áyin òwò ásidédèné" ("another woman's baby's faeces is usually very cold”). This means that no matter how one may tolerate another woman's child, there are certain things a woman would readily do for her own child, but would not be able to do for another woman's child. In other words, there are limits to what any woman can do for another woman's child, especially one whose mother is no longer alive. This is the reason why Ibibio women would prefer to live to take care of their own children themselves since they can never trust another woman to do this for them. In terms of assonance, all the vowel sounds of the Ibibio sound system are employed in this song.

Lullaby \# 9

Áyin dòp úyò-O!

Ùkà ákâ iñwáñ-O!

Ákâ ákéb $\wedge k$ ko nsék ákpààná.

Jfonno-ofon.

Nyin idiàdiá.

$\mathrm{A}-\mathrm{a}-\mathrm{a}-\mathrm{a}-\mathrm{a}-\mathrm{a}$ !

Odiokko-diok.

Nyin ino éwá!
Child, be quiet-O!

Your mother went to farm-O!

To harvest premature yams.

If they turn out to be good.

We shall eat them.

$\mathrm{A}-\mathrm{a}-\mathrm{a}-\mathrm{a}-\mathrm{a}-\mathrm{a}$ !

If it is bad.

We give to the dog! 


$$
\begin{array}{ll}
\text { A-a-a-a-a-a! } & \text { A-a-a-a-a-a! } \\
\text { Áyin-O! } & \text { Child-O! } \\
\text { Oh-oh-oh! } & \text { Oh-oh-oh! } \\
\text { Áyin-O! } & \text { Child-O! } \\
\text { Oh-oh-oh! } & \text { Oh-oh-oh! } \\
\text { Áyin-O! } & \text { Child-O! } \\
\text { Oh-oh-oh! } & \text { Oh-oh-oh! }
\end{array}
$$

\subsection{Analysis}

The above lullaby gives out basically the same information as the others. The intention is to quieten the child and keep her from further crying. To make this possible, the baby-sitter informs the child that his/her mother has gone to the farm to harvest premature yellow guinea yams (ákpààná). Àkpààná is the Ibibio name for yellow guinea yam (Dioscorea cayenensis lam) (Etuk, 2003: p. 49). There is uncertainty as to whether the yams will be good or not. However, the performer says that if the yams turn out to be good, they shall be eaten, if not, they will be fed to the dog. The picture painted here is that of extreme poverty since premature yams will never be harvested in a condition of plenty. In order to pass on the above information, the performer has employed some stylistic/aesthetic devices, two of which are: the use of declarative sentences, the use of interjection and repetition.

\subsubsection{The Use of Declaratives}

The performer makes use of declaratives like:

Ùkà ákâ iñwáñ-O!

(Your mother went to farm-O!)

Ákâ ákébıkko nsék ákpààná. (To harvest premature yams).

A declarative sentence is one that states a fact. From the view point of function, declarative statements usually state facts, information or ideas. The ideas or facts may be of various levels of credibility (Eka, 2017: p. 49). The motive behind the use of the declaratives is to give the child vital information that would aid in quietening him/her down.

\subsubsection{The Use of Interjections}

The performer makes use of interjections all through the song. Prominent examples include: “A -a-a-a-a-a!" (lines 6 and 9) and "Oh-oh-oh!" (lines 11, 13, and 15). Other lines of the song that contain interjection include Lines 1 and 2 :

$$
\begin{array}{ll}
\text { Áyin dòp úyò-O! } & \text { Child, be quiet-O! } \\
\text { Ùkà ákâ iñwáñ-O! } & \text { Your mother went to farm-O! }
\end{array}
$$

And lines 10, 12 and 14, which is a refrain:

Áyin-O!

These interjections mainly function as space-fillers as well as rhythm enhancers, to make the song melodious and rhythmic.

\subsubsection{The Use of Repetition}

The song makes use of repetition, to some extent. The repetitions are structured 
into the song as rhythm enhancers. The repetition occurs in lines 6 and 9 where the sound /a/occurs:

$$
\begin{array}{ll}
\text { A -a-a-a-a-a! } & \text { A -a-a-a-a-a! } \\
\text { Odiokko-diok. } & \text { If it is bad. } \\
\text { Nyin ino éwá! } & \text { We give to the dog! } \\
\text { A-a-a-a-a-a! } & \text { A-a-a-a-a-a! }
\end{array}
$$

Repetition also occurs in lines 10 to 15 , where “áyin” and "Oh!” occur:

$\begin{array}{ll}\text { Áyin-O! } & \text { Child-O! } \\ \text { Oh-oh-oh! } & \text { Oh-oh-oh! } \\ \text { Áyin-O! } & \text { Child-O! } \\ \text { Oh-oh-oh! } & \text { Oh-oh-oh! } \\ \text { Áyin-O! } & \text { Child-O! } \\ \text { Oh-oh-oh! } & \text { Oh-oh-oh! }\end{array}$

These repetitions enhance the intensity of the sounds in the song and also imbue it with the fluid liquidity that can potentially lull any child to sleep.

\section{Lullaby \# 10}

Cantor: Áyin dáiyá idáp-O!

Cantor: Child go to sleep-O!

Chorus: Kpà mbòhó, mbòhó, Kpa mbòhó!Chorus: Kpa mboho, mboho, Kpa mboho!

Cantor: Nsé áyin ké àdó?

Chorus: Kpà mbòhó!

Cantor: Àtúá-útùà àyin.

Chorus: Kpà mbòhó!

Cantor: Àtáñ-útàñ àyin!

Chorus: Kpà mbòhó!

Cantor: Idokko-idokko!

Chorus: Kpà mbòhó!

Cantor: Ikànná imé ábiəñ!

Chorus: Kpà mbòhó!

Cantor: Ikànná imé áyód!

Chorus: Kpà mbòhó!

Cantor: Ùkà ás $\Lambda \mathrm{k}$ àdi!

Chorus: Kpà mbòhó!

Cantor: Ùso ás $\Lambda \mathrm{k}$ àdi!

Chorus: Kpà mbòhó!

Cantor: Kàp dádáiyá idáp!

Chorus: Kpà mbòhó!

Cantor: Ùkà áyâdép mkpo!

Chorus: Kpà mbòhó!

Cantor: Ùso áyâdép mkpo!

Chorus: Kpà mbòhó!

Cantor: Kàp dáiyá idáp!
Cantor: What kind of child are you?

Chorus: Kpa mboho!

Cantor: Child given to crying!

Chorus: Kpa mboho!

Cantor: Talkative Child!

Chorus: Kpa mboho!

Cantor: Witty child!

Chorus: Kpa mboho!

Cantor: Cannot endure hunger!

Chorus: Kpa mboho!

Cantor: Cannot resist incessant crying!

Chorus: Kpa mboho!

Cantor: Your mother is coming!

Chorus: Kpa mboho!

Cantor: Your father is coming!

Chorus: Kpa mboho!

Cantor: Please go to sleep!

Chorus: Kpa mboho!

Cantor: Your mother would buy something!

Chorus: Kpa mboho!

Cantor: You father would buy something!

Chorus: Kpa mboho!

Cantor: Just go to sleep!

Chorus: Kpà mbòhó, mbòhó, Kpà mbòhó!Chorus: Kpa mboho, mboho, Kpa mboho! 


\subsection{Analysis}

This song makes a significant departure from the rest in that it has a cantor and a chorus. This implies that the baby sitter or minder is not alone in the performance of the song, but has rather invited other children to assist in taking care of the baby, as well as use them to form a backup or chorus for the lullaby that is captured above. The cantor makes the statement while the chorus provides the refrain. In the song, the cantor tells the child to go to sleep. When this statement does not bring out the desired effect, in frustration, the cantor asks:

Cantor: Nsé áyin ké àdó? (What kind of child are you?)

The minder therefore, determines to use any tactic at her disposal (aside from beating the baby), to persuade the child to have a change of mind and attitude.

\subsubsection{Levels of, and Rhetoric of Persuasion}

The minder determined to do her duties, undertakes the following three tactics and levels of persuasion on the child.

Level One-The Fault Enumeration/Intimidation/Stick Approach: This involves enumerating the child's negative qualities as a method of persuasion, in order to make the child do whatsoever the minder expects of her. This approach takes advantage of little children's love for praises. Where this is lacking, and if they are made to know that it is their fault that they are not being praised, they try to make amends, where possible. This approach can also be called the intimidation/Stick approach, because by flaunting the child's faults in order to compel it to do the minder's wish, this is intimidation; it is almost akin to meting out corporal punishment on the child, without using the physical rod to do so. This method of persuasion is meant to make the child to have a sense of shame and feel a sense of guilt for her negative qualities. In order to redeem himself/herself, the child in remorse tries to do whatsoever the minder expects of her, and in this case, to stop crying so as to be considered a good child:

1) Cantor: Àtúá-útùà àyin! (Child given to crying!)

2) Cantor: Àtáñ-útàñ àyin! （Talkative Child!)

3) Cantor: Idokko-idokks! (Witty child!)

4) Cantor: Ikànná imé ábioñ! (Unable to endure hunger!)

5) Cantor: Ikànná imé áyód! (Unable to resist incessant crying!)

When the above tactic does not have the desired effect, and the child does not stop crying, the cantor changes her tactics, and adopts the parental return strategy below.

Level Two-Parental Return Strategy: The cantor dangles the prospect of the child's parents returning to take care of their beloved child. In all climes, young children feel acutely, the absence of their parents. During this period of parental absence, the young child suffers from a sense of insecurity and drift, as opposed to the sense of security, love, warmth and stability it experiences when the parents are at home. This alone, is enough reason for young children to cry incessantly, until their parents return. The prospect of such a return gives the child some momentary sense of respite and euphoria. So the cantor dangles this pros- 
pect as a bait before the child thus:

1) Cantor: Ùkà ás $\Lambda$ àdi! (Your mother is coming!)

2) Cantor: Ùso ás $\Lambda \mathrm{k}$ àdi! (Your father is coming!)

3) Cantor: Kàp dádáiyá idáp! (Please go to sleep!)

Again, it must be noted that this strategy is mainly to make the child stop crying and go to sleep. However, this strategy fails to impress the child, and so the cantor adopts another approach, the cajoling approach.

Level Three-The Cajoling/Carrot Approach: This approach tries to persuade the child to do an adult's bidding through the use of physical inducements like gifts of toffees, or the promise of some delicacy. This approach takes advantage of the B.F. Skinner's theory of Operant conditioning. It states that a child would more likely repeat an action for which s/he was rewarded the first time, in order to be rewarded again (Essa, 2011: p. 138; Pound, 2011: pp. 92-99). In this song, the cantor adopts this approach by dangling before the child the prospect of his/her parents coming home with gifts (delicacies) for her alone, if only s/he would stop crying and keep quiet.

Therefore, the cantor goes into the third and deepest level of persuasion, by dangling before the child's mind's eye the prospect of her parents bringing home gifts and mouth-watering delicacies for her, if this would persuade her to stop crying:

1) Cantor: Ùkà áyâdép mkps! (Your mother would buy something!).

2) Cantor: Ùso áyâdép mkpo! (Your father would buy something!).

3) Cantor: Kàp dáiyá idáp! (Just go to sleep!).

This is a brilliant method of child persuasion that leaves a lasting impression on the young child, and on whoever comes in by stealth to watch the children perform this song.

The success of this song also depends on some of the stylistic and aesthetic devices deployed in the song. Some of these are the use of interjection, the use of epithets, the use of rhetorical question device, and repetition.

\subsubsection{The Use of Interjection}

Like all the other songs before it, this song is an exercise in the use of interjections. Even the refrain is in itself an interjection: “Kpà mbòhó!” Also, the declarative statements in the song are in themselves interjections, e.g.
1) Cantor: Ūkà ásık àdi!
(Your mother is coming!).
2) Cantor: Ùso ás $\Lambda \mathrm{k}$ àdi!
(Your father is coming!).
3) Cantor: Kàp dádáiyá idáp!
(Please go to sleep!).

These interjections not only add colour to the lyrics of the song, they also enhance the overall rhythm of the song.

\subsubsection{The Use of Rhetorical Question device}

The cantor makes use of the rhetorical question device, by asking the question:

Cantor: Nsé áyin ké àdó? (What kind of child are you?).

The answer to this question is quite evident to the singers and even to the ob- 
server. And the question is no sooner answered by the cantor herself, when she goes ahead to provide several descriptions of the child through the use of epithets.

\subsubsection{The Use of Epithets}

This aesthetic device is commonplace in African speech and song, where individuals are called pet-names either out of love and affection, or because the names are related to certain traits or behaviour modes the persons in question are generally known to exhibit. A typical situation is the one demonstrated in this song in relation to the baby that is the subject of this song, e. g.

1) Cantor: Àtúá-útùà àyin! (Child given to crying!).

2) Cantor: Àtáñ-útàñ àyin! (Talkative Child!).

3) Cantor: Idokko-idokko! (Comedian!).

The overall effect of the use of these epithets is to enhance the rhythm and sound quality of the song, in order to lull the baby for which it is being sung, to sleep.

\subsubsection{The Use of Repetition/Refrain}

This is another stylistic device which is prevalent in African Songs. There is no way an oral song is rendered that it does not undergo repetition (Okpewho, 2004: p. 71). One reason for this is that the lyric of the song may be short and so repetition serves to provide length. Apart from that, repetition serves to enhance the rhythm and cadence of the song. In this song, there is copious use of repetition/ refrain. For example, the chorus is a repetition/refrain when it repeats the words: "Kpà Mbòhó!" all through the song. The first line of the chorus repeats the refrain thrice, as follows: "Chorus: Kpà mbòhó, mbòhó, Kpa mbòhó!". The rest of the lines repeated by the chorus are only repeated once. It is only in the last line that we again see the chorus repeat the refrain thrice as in the first line above. These lines imbue the song with its unique cadence and rhythm.

\subsubsection{Assonance}

This is contained especially in the repetition of the phrase of the chorus: "Kpà mbòhó, mbòhó, Kpa mbòhó!" other sounds are also important in the song but the refrain stands out as the leading sound modulator in the song.

\section{Conclusion}

This paper set out to analyse the sound and sense inherent in select Ibibio lullabies. As a result, ten (10) lullabies have been examined within the context of the sound devices used as well as the meaning (sense impressions) embedded in the songs. The analyses show that the lullabies are rich in assonance and other sound devices, and provide music and rhythm that can effectively lull babies to sleep. This position is predicated on the fact that this literature is by its very nature, oral. Its main resource is the use of sounds, which naturally appeal to the ears. The child learns to listen first, before it begins to speak (Eyoh, 2016: p. 26). During this period, the baby learns to recognize the mother's and other close 
relatives' voices as they coo reassuringly to it. When a minder is employed, the child also learns to recognize her voice and to respond to it. The reassurance in the mother's or minder's cooing or crooning voice in addition to the use of assonance and other sound elements in songs, effectively quieten the child or lull it to sleep. The effect of sounds performed orally in song can never be underestimated. According to Okpewho (2004: p. 70): The appeal of sound can indeed be so strong, the premium placed on it is so high that performers can at times indulge in certain "nonsense" words or other kinds of sound either for sheer entertainment effect or perhaps to fill in a gap...

Lullabies are one subgenre where performers use sounds to create entertainment effects as supported above, especially the deployment of assonance and other sound elements.

From the findings of this paper, lullabies are also rich in other stylistic and aesthetic devices such as repetition/refrain, rhetorical question device, and use of epithets, among others. The meaning of each lullaby enhances the rhythm and stands it out as a veritable tool of persuasion that has not lost its hold on the imagination of both the Ibibio child as well as the performers of the song. In effect, lullabies are veritable vehicles for the transmission of cultural values, norms and mores in an increasingly unstable and changing world. The profundity of thought inherent in these lullabies and the aesthetic devices that convey them prove over time that Ibibio lullabies are veritable poetry comparable to the best poetry anywhere in the world. These lullabies should be subjected to further aspects of study, while documentation and preservation of these texts should be given priority, as they are now being threatened by extinction as a result of the encroachment of new modern forms of communication and entertainment like the television and the new media.

\section{Conflicts of Interest}

The author declares no conflicts of interest regarding the publication of this paper.

\section{References}

Chukwuma, H. (1994). Igbo Oral Literature: Theory and Tradition. Abak: Belpot.

Eka, D. (2017) Elements of Grammar and Mechanics of the English Language. Uyo: Samuf.

Essa, E. L. (2011). Introduction to Early Childhood Education (6th ed.). Belmont, CA: Wadsworth Cengage Learning

Essien, O. (1986). The Ibibio Language: Classification and Dialects. Nigeria Magazine, 54, 10-18.

Essien, O. (1990). A Grammar of the Ibibio Language. Ibadan: Ibadan University Press.

Etuk, I. (2003). Ethnology: Conventional and Traditional Uses of Plants. Uyo: The Verdict Press.

Etuk, U. (1989). Ibibio Children's Oral Poetry. Calabar Studies in Language (CASIL), 9, 31-38. 
Eyoh, L. (2003). The Poetry of Ibibio Work and Moonlight Songs. Journal of Nigerian English and Literature (JONEL), 4, 104-118.

Eyoh, L. (2016). The Effective Use of English (Vol. 1). Uyo: Scholars Press (Nig). Ltd.

Finnegan, R. (2012). Oral Literature in Africa. Cambridge: Open Book Publishers. https://doi.org/10.11647/OBP.0025

Ikiddeh, I. S. (1997). Positioning the Spoken Word. A keynote Address at the 14th ICALEL, May 1997. Later published in Currents in African Literature and the English Language (CALEL), 2004: 1-9.

Iwoketok, U. (1995). Ibibio Children's Games: Analysis of Educational and Social Values. Journal of Research in Education and the Humanities (JOREH), 3, 94-104.

Iwoketok, U. (2001). Ibibio Children's Games as a Means of Learning and Preserving Cultural Values. In Studies in Language and Literature (pp. 34-46). Jos: Mazlink.

Iwoketok, U. (2005). Symbolism in Ibibio Children's Play Songs. Usem: Journal of Languages, Linguistics and Literature, 1, 95-108.

Kolawole, M. E. (2007). Women's Oral Genres. In T. Olaniyan, \& A. Quayson (Eds), African Literature: An Anthology of Criticism and Theory (pp. 92-96). Malden, MA: Blackwell Publishing.

Machado, J. M. (1999). Early Childhood Experiences in Language Arts: Emerging Literacy. Albany, NY: Delmar Publishers.

Okpewho, I. (2004) African Oral Literature: Background, Character and Continuity. Bloomington, IN: Indiana University Press.

Onuekwusi, J. A. (2015). Fundamentals of African Oral Literature. Owerri: Alphabet.

Pound, L. (2011). Influencing Early Childhood Education: Key Figures, Philosophies and Ideas. New York: McGraw Hill \& Open University Press.

Udo, E. (1983) Who Are the Ibibio? Onitsha: Africana-Fep. 